by making the mean brightness of white (Ao) stars near the sixth magnitude equal to the mean of their visual magnitudes in Harvard Circular I7o.

The photovisual scale was obtained in precisely the same manner, isochromatic plates being employed. Final photovisual magnitudes were obtained for 339 stars between magnitudes $2 \cdot I$ and $I 7 \cdot 5$. About 300 stars are common to both lists, and for these colour indices are consequently available; for the bright stars this is small, or even negative, at the seventeenth photovisual magnitude the smallest value is 0.6 or 0.7 . That the faint stars are all relatively red is thus confirmed.

Meteorology of THE Sun.-A lecture delivered before the Royal Meteorological Society last March by Prof. W. G. Duffield is reported in full in the Quarterly Journal of the Society. Whilst, of course, primarily adapted to the needs of meteorologists, it is too valuable an essay on the present position of solar research to be neglected by anyone interested in such work. The subject was divided into a number of sections; one of these, dealing with the pressure in the sun's atmosphere, has special interest in consequence of Prof. Duffield's own work on the effects of pressure on spectra. Electrical conditions in the sun's atmosphere are considered in another section, containing the interesting suggestion that the "facular masses" shown on spectroheliograms owe their luminosity to a continuous display of lightning between their several parts, or to a bombardment by negative electrons. Prof. Duffield also suggests that solar rotation is the cause of sun-spots and filaments, his theory being that the differential velocities of the various layers of the solar atmosphere set up vortices; these seen end-on are sun-spots, when floating lengthwise appear as filaments. Although neither of these ideas is entirely novel, yet both go a little further than their precursors.

The paper is illustrated by a number of useful diagrams, and contains reproductions of some fine spectroheliograms.

Variable Stars. - Two papers dealing with investigations carried on at Princeton Observatory appear in the Proceedings of the American Philosophical Society, No. 216 . In one of these Dr. Dugan (p. 54) gives some recent results obtained in the case of the eclipsing variables RT Persei and $z$ Draconis, both cases where the light curves have demonstrated ellipticity of figure, exchange of radiation, and possibly darkening at the limb. For RT Persei the shape of the light curve possibly indicates that the advancing side of the brighter component is brighter than the following. Some recent observations of the secondary minima show that the eclipses are now coming forty minutes earlier than the times predicted from the original elements derived from observations taken about seven years ago. Extending the period of observation by data from Harvard results in a reduction of the average period by one second. Using this shorter period the residuals reveal two periodic terms, the shorter of which closes in about 4000 eclipse periods, i.e. about nine years, and with a coefficient of five minutes. This is of the order of magnitude of that to be expected from the revolution of the line of apsides caused by the observed prolateness. Necessary additional observations are being undertaken. Similar results have been obtained for $z$ Draconis. In both stars the light at minimum is distinctly redder than before. In the other paper Mr. R. J. McDiarmid deals with the algol variables, TV, TW, TX Cassiopeiæ, and 'T I.eonis Minoris. Secondary minima have been established in the light curves of TW Cass. and T Leo. NO. 2380 , VOL. 95]
Min. The light curve of TV Cass. indicates an increase of brightness between primary and secondary eclipse, and the light curve of TX Cass. affords evidence of darkening towards the limb.

Short Period Variable Stars.-Von G. Hornig (Ast. Nach., No. 4808) publishes the results of numerous observations by Argelander's method of several bright variable stars of short period. The elements calculated from these observations, together with mean light curves, are given for the three Cepheid variables RT Aurigæ (74 obs.), $\eta$ Aquilæ (rgo obs.), $\delta$ Cephei (396 obs.), for the Geminid variable $\zeta$ Geminorum (I 1 I obs.), and for the two stars of $\beta$ Lyræ type, $\mu$ Herculis (208 obs.) and $\beta$ Lyræ (327 obs.). Elements determined by Breson from coservations of $\zeta$ Geminorum, $\eta$ Aquilæ, $\delta$ Cephei, and $\beta$ Lyræ, and by Lau in the case of $\delta$ Cephei and $\beta$ Lyræ, are compared. It is stated that the lack of correspondence in the secondary maxima of light curves determined by different observers is due to their varied "colour-perception," as are also the minor differences of more or less pointed or flattened maxima.

\section{THE MANCHESTER MEETING OF THE BRITISH ASSOCIATION.}

$A^{S}$ already announced, the meeting will be opened $\mathrm{A}$ on September 7 and close on September Ir. The following are among the sectional arrangements:-In Section A there will be discussions on radio-active elements and the periodic law (opened by Prof. F. Soddy); spectral classification of stars and the order of stellar evolution (opened by Prof. A. Fowler); thermionic emission (opened by Prof. O. W. Richardson); and papers by Prof. W. H. Bragg and W. L. Bragg, on X-rays and crystal structure; G. H. Hardy, on prime numbers; and Prof. A. N. Whitehead, on time, space, and relativity.

In Section B there will be an exhibition and explanation of diagrams by Dr. Dalton, illustrating his atomic theory, an experimental paper by the Hon. R. J. Strutt on active nitrogen, a discussion on smoke prevention, experimental papers on combustion, a paper by Prof. W. J. Pope on liquid crystals (with experiments), and a discussion on homogeneous catalysis.

In Section C Dr. G. Hickling will give an account of the geology of Manchester and district; Prof W. Boyd Dawkins, papers on the classification of the tertiary strata by means of the Eutherian mammals, and the geological evidence of the antiquity of man in Britain. There will be a joint discussion with Section $\mathrm{E}$ on the classification of land forms (opened by Dr. J. D. Falconer). Papers will be read by Dr. A. H. Cox and A. K. Wells on the Ordovician sequence in the Cader Idris district (Merioneth); Prof. T. G. Bonney, on the north-west region of Charnwood Forest; Dr. A. Vaughan, on the shift of the western shore-line in England and Wales during the Avonian period; Prof. W. G. Fearnsides, on a contour map of the Barnsley coal seam in Yorkshire. A discussion on radio-active problems in geology (opened by Sir E. Rutherford). Papers will be read by Prof. C. A Edwards on twinning in metallic crystals; Prof. W.J. Sollas, on the restoration of certain fossils by serial sections; Dr. J. W. Evans, on the isolation in the directions image of a mineral in a rock-slice; Dr. $G$. Hickling, on the micro-structure of coal; D. M. S. Watson, on vertebrate life zones in the Permo-Trias; Dr. A. Wilmore, on the Carboniferous limestone zones of north-east Lancashire; H. Day, a brief criticism 
of the fauna of the limestone beds at Freak Cliff and Peakshill, Castleton, Derbyshire; Dr. Jowett, a preliminary note on the glacial geology of the western slopes of the southern Pennines. It is intended to arrange, if possible, two or three afternoon geological excursions in the neighbourhood of Manchester. On Saturday there will be a whole-day field excursion to Edale and Castleton.

In Section $D$ there will be the following communications:-A discussion on chromosomes and heredity (to be opened by Prof. E. W. MacBride), and a series of papers on material collected in or en route to Australia in connection with the visit of the association last year. Prof. Herdman will contribute notes on the plankton collected between Liverpool and Fremantle (viâ the Cape), Dr. J. H. Ashworth will give an account of larvæ of Lingula taken in the Red Sea and Indian Ocean, Prof. Dendy will give notes on his collecting in Australia, and Prof. Poulton will exhibit insects taken in Australia. Mr. Launcelot Harrison will give a paper on the relation of the phylogeny of the parasite to that of the host. $\mathrm{He}$ will advance the views that in the case of total obligate parasites, closely related parasites will be found to occur on phyletically connected hosts, and therefore the study of such parasites may give valuable indications as to the phylogeny of the host; for instance, the Mullophaga found on the New Zealand Apteryx indicate that this bird is a Ralline bird, and not a Ratite. Lieut.-Col. Lieper will give a demonstration upon his recent work on Bilharzia in Egypt, during the course of which he has been able to elucidate the life-history of this parasite of man. Other papers promised are:-Prof. F. J. Cole and N. B. Eales, materials for a graphic history of comparative anatomy; Prof. Hartog on the movements of chromosomes in cell-division; Prof. Hickson on the distribution of sea-pens; Dr. Dixey and Dr. Cameron on entomological subjects; Prof. Meek on the distribution of fish and (another paper) on the future of scientific literature in relation to the war; Dr. J. S. Thomson on the elasmobranch fore-brain; Dr. W. C. Mackenzie on the vermiform appendix in Monotremes and Marsupials; Dr. C. Powell White on the regeneration of the tail in lizards; F. W. Ash on secondary sex-characters.

The arrangements for Section E are:-Papers by A. R. Hinks on the map on the scale of $1: 1,000,000$; O. J. R. Howarth on geographical considerations arising out of the visit to Australia in 1914; Prof. J. W. Gregory on relations of the central lakes of Westralia; Dr. R. N. Rudmose Brown on the growth of cities in Australia; J. McFarlane on the Burrinjuck dam and the Yanco irrigation area; a joint discussion with Section $C$ on the classification of land forms; a joint discussion with Section $\mathrm{H}$ on racial distribution in the Balkans (opened by Prof. G. Elliot Smith); papers by P. M. Roxby on north China and Korea; Dr. R. N. Rudmose Brown on Spitsbergen before the war; $R$. Curtis on the distribution of population in the district round Leek; T. Edwards on a rainfall map of Lancashire and Cheshire; Dr. F. Oswald on a recent visit to the Caucasus; J. Parry on lake movements as observed in Lake Vyrnwy, and one on afforestation, being continuation of the paper read at the Southport meeting in 1903 .

Among the papers to be read in Section G are :Prof. Asakawa and Prof. Petavel on an experimental investigation of the thermal efficiency of a gas engine; Prof. W. M. Thornton on the apparent specific heats in gaseous explosions; E. C. Mills on a unit gasproducer for steam boilers; A. A. Griffith on an investigation of the thermal conductivity of thin-air films; Prof. Batho on torsion stresses in framed structures and thin-walled prisms; A. Robertson on the strength of iron and steel struts; Dr. Eccles and A. J. Makower on electric oscillations in coupled circuits; Prof. G. W. O. Howe on the capacity of aerials of the umbrella type; Prof. Miles Walker on the eddy current losses in the end-plates of large turbo-generators; Prof. Walker will also describe some experiments to determine whether there exists mutual induction between masses; Prof. W. Morgan on the automobile and war; T. H. Brigg will describe a new method of attaching horses to vehicles.

In Section $H$ the president's address will be followed by a discussion (to be opened by Prof. Elliot Smith) on the influence of ancient Egyptian civilisation on the world's culture; Prof. Flinders Petrie will deal with Egyptian jewelry, describing in particular the treasure of Lahun; Dr. Alan Gardiner will discuss the evidence pointing to a common parent for the Phenician, Greek, and Sabæan alphabets afforded by the inscriptions on strelæ, undecipherable as any form of Egyptian writing, discovered by Prof. Petrie at Sinai in 1905; Prof. Giuffrida-Ruggeri, of Naples, has forwarded a paper on the racial origins of the carly Neolithic and copper-using peoples of Egypt, which will be presented and discussed by Prof. Elliot Smith, and Miss Margaret Murray, in a communication on royal marriage and matrilineal descent, and Mr. Hocart, in a paper on the quest for immortality, will be concerned largely with the Egyptian evidence. Racial distribution in the Balkans will form the subject of a discussion in joint session with Section E. Papers will be read by R. M. Dawkins on the Greel element in Asia Minor; and Dr. Rivers on analysis of ceremonial and descent in Ambrim. In physical anthropology Prof. Keith will present and discuss, at the request of the author, une Application anthropologie à l'Art militaire, by Prof. E. Manouvrier, of Paris, which deals with the desirability of classifying troops acording to certain anthropological characters; and Prof. Elliot Smith will exhibit the most ancient human remains from India. There will be a visit to the Roman fort at Ribchester, the exploration of which has been carried on under the auspices of Manchester University. The main features of the fort will be described by Prof. Haverfield, Prof. W. B. Anderson, who has been in charge of the excavations, and others.

In Section I it was hoped to have had a discussion on the physiological conditions necessary for the maximum efficiency of the factory worker, but the absence, owing to circumstances created by the war, of so many who could have spoken authoritatively on the subject has necessitated its deletion from the programme. Prof. B. Moore is giving a popular lecture during the meeting, in which he will have a good deal to say on the physiology of factory labour. Prof. Bayliss is to speak on the mode of action of urease; Dr. Edridge-Green on some fundamental facts of vision and colour vision; and Prof. B. Moore on the action of light on certain inorganic and organic substances. Some local contributions are kinematograph films by Dr. Graham Brown; the presence of copper in animal and vegetable tissues by Dr. C. Powell White; some laws of fat absorption, and the micro-chemical differentiation of tissue fats and lipoids, by Drs. Lamb and Holker. Dr. C. E. Lea is to give a demonstration of the detection of certain cardiac disorders by the electrocardiograph. Other contributors are Dr. Sarah M. Baker, on the liquid pressure theory of muscular contraction; Prof. W. H. Thompson on arginine and creatine formation, and on the effects of tetanisation on the creatinine and creatine of the muscles of the cat; Dr. John Tait on thrombokinase; Drs. Tait and Pringle on the elas- 
ticity of the strophanthinised heart; and Prof. P. T. Herring on the effect of thyroidectomy on the adrenincontent of the suprarenals.

In Section $\mathrm{K}$ a lecture is to be given by $\mathrm{W}$. Lawrence Balls on cotton, and the following papers will be read:--Prof. F. O. Bower on the evolution of some ferns, in particular the Dipterids and the allies of the common bracken; Dr. D. H. Scott on the fossil plants of the genus Heterangium; Dr. Marie C. Stopes on the fossils of the Aptian (Greensand) period, including some of the oldest flowering plants of this country showing internal structure; Prof. Osborn on the morphology of Selaginella uliginosa, and his wife on some Australian fossils belonging to the genus Zygopteris; Dr. Ellis on fossil bacteria and fossil fungi; Dr. Sarah M. Baker on a new hypothesis regarding the ascent of sap in plants; Dr. Marion Delf on the effect of temperature on the permeability of protoplasm to water; Miss Prankerd on Statoliths; Prof. W. B. Bottomley on the formation of auximones from nitrogenous organic substances; Prof. Julius MacLeod on the expression by measurements of specific characters with special reference to the mosses; Dr. J. C. Willis on the evolution of the flora of Ceylon.

In Section $L$ the following discussions may be expected:-On methods and content of history as a subject of school study; on military training in schools; on education of women in relation to their careers; on education and industry.

In Section $M$ papers will be read by Prof. J. Hendrick on composition and uses of seaweed; by Prof. W. Somerville on accumulation of fertility in grass land; by D. Macpherson on types of hill grazings, their economic value and importance; and discussions will take place on probable effects of the war on the future of British agriculture, and the economics of milk production.

\section{THE STUDY OF HEREDITY.}

THE popularity of problems of genetics as subjects for research and discussion is well illustrated by the May number of the American Naturalist (vol. xlix., No. $58 \mathrm{I})$, every paper in which bears on one or other of such problems. Of especial interest is Prof. Jacques Loeb's article on the nature of the conditions which determine or prevent the entrance of the spermatozoon into the egg. It is well-known that in normal fertilisation, the entrance of the spermatozoon is followed by the formation of a membrane around the egg, so that the entrance of other spermatozoa is prevented. But, as Prof. Loeb has already recorded in his work on "Artificial Parthenogenesis and Fertilisation," seaurchin eggs the development of which has been started by treatment with hypertonic sea-water can be afterwards fertilised, a spermatozoon being capable of entering a blastomere-at least up to the stage of the eighth cleavage-and inducing "a distinct and clear membrane formation " around it. This shows that the entrance of a male cell is not necessarily prevented by "the changes underlying development." But eggs by treatment with butyric acid can be induced to form a membrane. If this membrane remain unbroken subsequent fertilisation becomes impossible, though parthenogenetic segmentation may begin; if, however, the membrane be ruptured by shaking, a spermatozoon can enter and the egg undergoes normal development. Hence it may be inferred that the physical condition of the surface of the egg-howsoever modified-is the immediate determinant of the admission or exclusion of a spermatozoon. This view is supported by Loeb's experiments in cross-fertilisation, which show that the sea-urchin (Strongylocentrotus) egg admits the sperm of an echinoderm of another class only in a hyper-

NO. 2389 , VOL. 95] alkaline solution. On the other hand, eggs cannot be fertilised by sperms of their own species in sea-water containing an excess of neutral chlorides. From all these facts Loeb is inclined to draw the conclusion that the tension of the surface of the egg may explain the engulfment or exclusion of the spermatozoon. But it is obvious that in the case of normal fertilisation this surface-condition is "induced from within the egg by changes caused by the entrance of the spermatozoon "- - deduction made by biologists long before the study of "experimental embryology" had become fashionable.

In the same number of the American Naturalist Dr. Raymond Pearl continues his studies in heredity with reference to questions of practical breeding with a paper on Mendelian inheritance of fecundity in the domestic fowl." Large egg-yield, especially-during the winter months, is shown by experiment to depend upon the presence of two Mendelian factors in the germ-cells, so linked with sex-determining characters that the female is heterozygous. Thus is confirmed the belief of some poultry-fanciers that the father is of greater importance than the mother for the establishment of a "good laying strain." In the Biological Bulletin (vol. xxviii., No. 3) Dr. M. R. Curtis describes a Rhode Island red hen with the terminal part of her oviduct aborted. Consequently the eggs--which were produced in the normal way--passed out into the body cavity and their food materials were absorbed by the bird's tissues without disturbance of the metabolism.

A recent number of our British Journal of Genetics (vol. iv., No. 4) contains a noteworthy paper, by Dr. $H$. Drinkwater, on the inheritance of brachydactyly in human families. The observations on this condition made by Dr. W. C. Farabee in North America, and by Dr. Drinkwater in this country are summarised in Mr. Bateson's book, "Mendel's Principles of Heredity," and brachydactyly has become a classical example of a simple Mendelian dominant-character. Dr. Drinkwater now describes a second family in England, and proves it to be a branch of the American stock studied by Dr. Farabee. The most important feature of the present study is found in the very beautiful series of radiographs of the brachydactylous hands and feet. The second phalanx is not really absent, but remains in a rudimentary condition, and becomes usually united to the base of the terminal phalanx.

Colour phenomena in animal and plant inheritance naturally continue to attract the attention of experimenters. A short paper on the "English" rabbit, by Prof. W. E. Castle and P. B. Hadley (Proc. Nat. Acad. Sci., vol. i.) is worthy of note. The "standard" coat in these rabbits is white with black muzzle, ears, and spots on back and flanks. Breeding experiments have shown that this "standard" coloration is really a mark of hybridity, for when mated together such rabbits yield a progeny half of which are either without the back and flank black markings or with these greatly exaggerated. The present paper describes how a "standard English" buck was mated with "Belgian hare" does, and how one of his dark-coated sons from this cross was afterwards mated to the same does; the result was that this latter begot distinctly darker offspring than his father, the "modal grades" being respectively $2 \cdot 0$ and $3 \cdot 25$. "Yet the father," write the authors, "contained only a single dose (one gamete) of English pattern, and the son derived his English pattern exclusively from this same source. Hence the English unit-character had changed quantitatively in transmission from father to son. This seems to us conclusive evidence against the idea of unit-character constancy or gametic purity.'

Dr. L. J. Cole's paper on the inheritance of colour in pigeons (Rhode Island Agric. Exp. Station, Bulletin ${ }^{1} 5^{8}$ ) was summarised in Nature last year (vol. xciv., 